
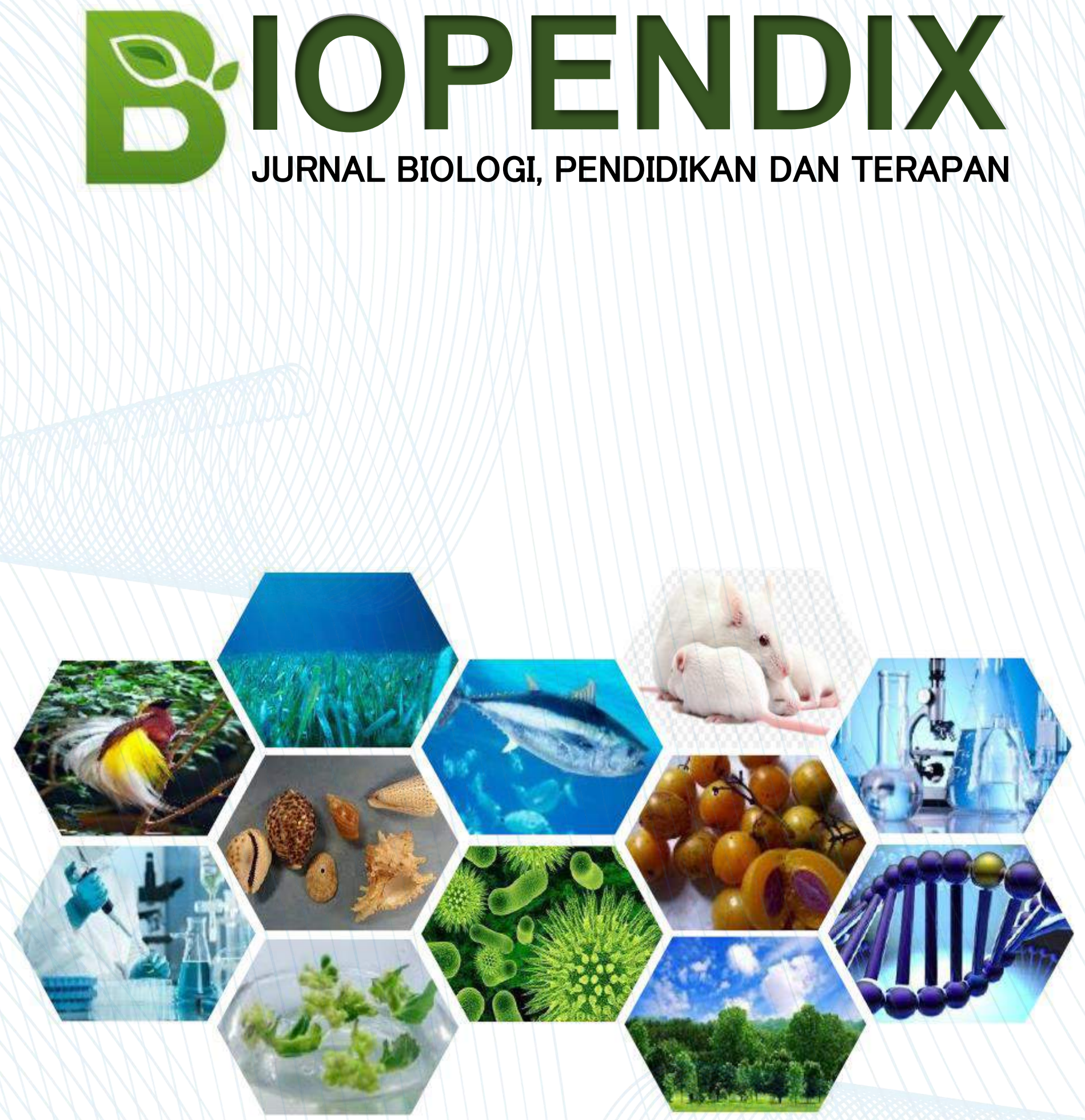

PUBLISHER BY:

BIOLOGY EDUCATION, UNPATTI AMBON - MALUKU 


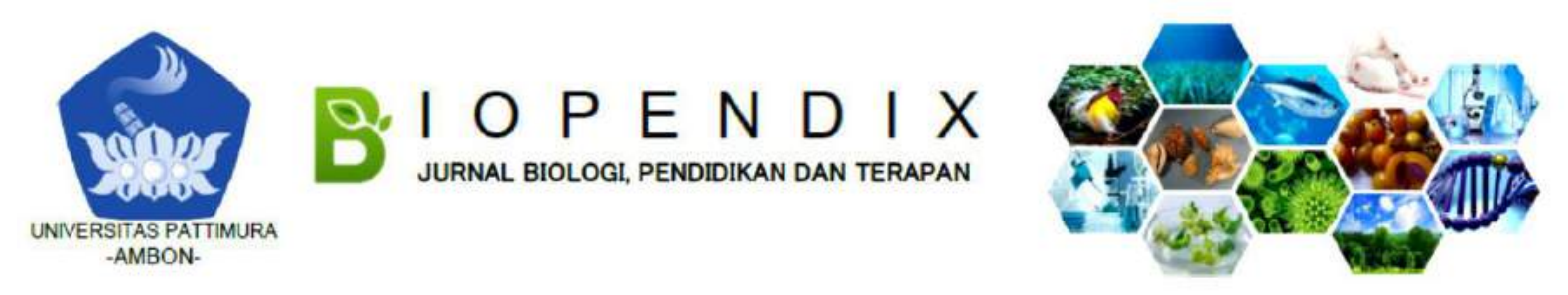

\title{
UJI KUALITAS ORGANOLEPTIK DAN KADAR SERAT \\ PADA PRODUK PANGAN JELLY DRINK BERBAHAN DASAR BUAH AREN (Arenga pinnata Merr) SERTA IMPLIKASINYA PADA MASYARAKAT TANIWEL
}

\author{
Aprilya Claudia Aliputty ${ }^{1}$, Fredy Leiwakabessy², Merry Pattipeilohy*2 \\ ${ }^{1}$ Alumni Program Studi Pendidikan Biologi; ${ }^{2}$ Program Studi Pendidikan Biologi \\ *Corresponding author: Merry Pattipeilohy; e-mail: mpattipeilohy.unpatti@gmail.com
}

\begin{abstract}
Background: Sugar palm plants (Arenga pinnata MERR) are plants that have great potential in terms of food shortages. Currently the main product of the palm sugar plantations is the sap of tapping male flowers made of palm sugar, sageru, vinegar and alcoholic drinks. In addition, all parts of the palm tree are useful and can be used for a variety of needs, ranging from roots, stems, leaves, fibers, and the results of their production are roomie, flour and fruit. This study aims to determine the organoleptic quality and jelly fiber content of drinks made from palm fruit (Arenga pinnata Merr).

Methods: This study uses a gravimetric method to determine the levels of fiber in jelly drinks and hedonic methods to test organoleptics.

Results: Based on the results of the analysis it can be concluded that the levels of jelly fiber drinks made from palm fruit are different. In the U-I test code the fiber content was 0,3446 while in the U-II test code it was 0,3127 . Organoleptic test on jelly drink made from palm fruit showed the average for color parameters of 3 , taste of 4.8 , texture of 4.9 , and suppleness of 4.5 . This research is implied in the form of leaflets to the Taniwel community.

Conclusion: The levels of jelly fiber drinks made from palm fruit are different. Organoleptic testing was carried out by 20 panelists who had tested the parameters of color, taste, texture and suppleness.
\end{abstract}

Keywords: Jelly Drink, Palm Sugar, Fiber Content, Organoleptic

\section{Abstrak}

Latar Belakang: Tanaman aren (Arenga pinnata MERR) adalah tanaman perkebunan yang sangat potensial dalam hal mengatasi kekurangan pangan. Saat ini produk utama tanaman aren adalah nira hasil penyadapan bunga jantan yang dijadikan gula aren, sageru, cuka dan minuman beralkohol. Selain itu hampir semua bagian pohon aren bermanfaat dan dapat digunakan untuk berbagai kebutuhan, mulai dari akar, batang, daun, ijuk, maupun hasil produksinya yaitu nira, tepung dan buah. Penelitian ini bertujuan untuk mengetahui kualitas organoleptik dan kadar serat jelly drink berbahan dasar buah aren (Arenga pinnata Merr).

Metode: Penelitian ini menggunakan metode gravimetrik untuk mengetahui kadar serat pada jelly drink dan metode hedonik untuk pengujian organoleptik.

Hasil: Berdasarkan hasil analisis dapat disimpulkan bahwa kadar serat jelly drink berbahan dasar buah aren berbeda-beda. Pada kode ulangan U-I kadar serat sebesar 0,3446 sedangkan pada kode ulangan U-II sebesar 0,3127. Pengujian organoleptik pada jelly drink berbahan dasar buah aren menunjukan rerata untuk parameter warna sebesar 3 , rasa sebesar 4,8, tekstur sebesar 4,9, dan kekenyalan sebesar 4,5. Penelitian ini diimplikasikan dalam bentuk leaflet kepada masyarakat Taniwel.

Kesimpulan: Kadar serat jelly drink berbahan dasar buah aren berbeda-beda. Pengujian organoleptic dilakukan oleh 20 orang panelis yang sudah terlatih dengan melakukan pengujian pada parameter warna, rasa, tekstur dan kekenyalan.

Kata Kunci: Jelly Drink, Buah Aren, Kadar Serat, Organoleptik 


\section{PENDAHULUAN}

Tanaman aren (Arenga pinnata MERR) adalah tanaman perkebunan yang sangat potensial dalam hal mengatasi kekurangan pangan (Effendi, 2009) Saat ini produk utama tanaman aren adalah nira hasil penyadapan bunga jantan yang dijadikan gula aren, sageru, cuka dan minuman beralkohol (sopi minuman tradisional Ambon). Selain itu hampir semua bagian pohon aren bermanfaat dan dapat digunakan untuk berbagai kebutuhan, mulai dari akar, batang, daun, ijuk, maupun hasil produksinya yaitu nira, pati/tepung dan buah (Sunanto, 1993). Buah aren berupa buah buni, yaitu buah yang berair tanpa dinding dalam yang keras. Tiap buah aren mengandung tiga biji. Buah aren yang setengah masak, kulit bijinya tipis, lembek dan berwarna kuning. Inti biji (endosperm) berwarna putih agak bening dan lunak. Inti biji inilah yang disebut kolang-kaling dan biasa digunakan sebagai bahan makanan (Lutony, 1993).

Dari segi komposisi kimia, kolangkaling memiliki nilai gizi sangat rendah, akan tetapi serat kolang-kaling baik sekali untuk kesehatan. Serat kolang-kaling dan serat dari bahan makanan lain yang masuk kedalam tubuh menyebabkan proses pembuangan air besar teratur sehingga bisa mencegah kegemukan (obesitas), penyakit jantung koroner, kanker usus, dan penyakit kencing manis. Ternyata masih sedikit olahan kolang-kaling yang dijadikan produk pangan, berdasarkan hasil penelitian tentang buah aren kolang-kaling telah dijadikan manisan, permen jelly, dan yang paling sering digunakan oleh masyarakat adalah untuk campuran es buah serta minuman segar lainnya (Muchtadi, 2000). Jelly drink merupakan produk pangan yang berbentuk gel yang kenyal, yang biasa dikonsumsi sebagai penunda rasa lapar. Gel terbentuk melalui mekanisme pembentukan junction zone (seperti karagenan dan konjak) bersama dengan gula dan asam. Minuman ini memiliki kadar kekentalan diantara sari buah dan jelly (Sugiarso, 2015).

Dilihat dari manfaat tanaman aren, buah aren belum banyak dimanfaatkan oleh masyarakat Maluku secara umum, dan masyarakat Kecamatan Taniwel secara khusus. Di daerah Pulau Seram khususnya
Kecamatan Taniwel ijuk pohon aren dijadikan sebagai sapu lidi dan air nira pada pohon aren dijadikan sebagai gula merah,sopi, sageru, dan asam cuka. di daerah kecamatan Taniwel buah aren di buang begitu saja karena tidak dimanfaatkan oleh masyaraka Taniwel, sehingga perlu memperkenalkan invovasi baru pengolahan kolang-kaling. Penelitian ini akan diimplikasikan pada masyarakat berupa leaflet yang berisikan cara kerja dari pembuatan jelly drink kepada masyarakat, sehingga akan menambah pengetahuan masyarakat Kecamatan Taniwel terkait dengan pemanfaatan kolang kaling buah aren sebagai bahan dasar pembuatan jelly drink dan juga dapat meningkatkan nilai ekonomis masyarakat.

Leaflet merupakan media berbentuk selembar kertas yang diberi gambar dan tulisan pada kedua sisi kertas serta dilipat sehingga berukuran kecil dan praktis dibawa. Dengan ukuran A4 dilipat tiga, media ini berisikan gagasan secara langsung kepokok persoalannya dan memaparkan cara melakukan tindakan secara pendek dan lugas. Tujuan dari Leaflet ini adalah sebagai bahan informasi kepada masyarakat tentang pemanfaatan buah aren yang diolah menjadi sebuah bahan pangan alternative (Ratumanan, 2004).

\section{METODE}

Tipe penelitian yang digunakan adalah penelitian deskriptif untuk melihat kualitas organoleptik dan kadar serat pada jelly drink berbahan dasar buah aren. Tempat pengambilan sampel di hutan Tihunone Desa Nuniali Kecamatan Taniwel Kabupaten Seram Bagian Barat. Pembuatan jelly drink di Laboratorium Biologi Dasar FKIP Universitas Pattimura. Pengujian Kadar Serat pada jelly drink di Laboratorium Kimia Dasar FMIPA Universitas Pattimura Ambon. Uji organoleptik dilakukan untuk menilai warna, rasa, tekstur dan kekenyalan (kusioner). Waktu Penelitian dilaksanakan pada tanggal 24 Juni 2019 s/d 24 Juli 2019. Sampel dalam penelitian ini adalah 100 buah aren dari populasi dengan ciri-cirinya buah yang muda. Variabel yang digunakan dalam penelitian yaitu: variable bebas dan 
variabel terikat. Analisis ini dilakukan secara deskriptif yaitu menggambarkan hasil analisis kadar serat dalam bentuk tabel dan juga menggunakan rumus perhitungan kadar serat. Sedangkan untuk uji Organoleptik dalam menilai seberapa besar minat konsumen terhadap produk yang dihasilkan, panelis akan memberi penilaian khusus terhadap warna, tekstur, rasa, dengan menggunakan skala hedonik.

\section{HASIL DAN PEMBAHASAN}

Uji Kadar Serat Pada Produk Pangan Jelly Drink Berbahan Dasar Buah Aren (Arenga pinnata merr)

Hasil penelitian uji kadar serat pada produk pangan jelly drink berbahan dasar buah aren dapat dilihat pada Tabel 5 .

Tabel 5. Hasil Uji Kadar Serat Pada Produk Jelly Drink

\begin{tabular}{lllll}
\hline $\begin{array}{c}\text { Kode } \\
\text { Ulangan }\end{array}$ & \multicolumn{1}{c}{$\begin{array}{c}\text { Berat } \\
\text { Sampel (gr) }\end{array}$} & $\begin{array}{c}\text { Berat } \\
\text { Serat (gr) }\end{array}$ & $\begin{array}{c}\text { Kadar } \\
\text { Serat (\%) }\end{array}$ & $\begin{array}{c}\text { Rata-rata kadar } \\
\text { Serat (\%) }\end{array}$ \\
U-I & 5,1935 & 0,0179 & 0,3446 & 0,32865 \\
U-II & 5,2122 & 0,0163 & 0,3127 & \\
\hline
\end{tabular}

Keterangan: UI: Ulangan Pertama; UII: Ulangan Kedua

Dari tabel 5 terlihat bahwa kadar serat produk pangan jelly drink berbahan dasar buah aren berbeda-beda pada kedua kode ulangan. Pada kode ulangan U-I kadar serat sebesar 0,3446 sedangkan pada kode ulangan U-II sebesar 0,3127. Rata-rata kadar serat pada Tabel 5 yaitu 0,32865.

\section{Uji organoleptik Jelly Drink Berbahan Dasar Buah Aren (Arenga pinnata merr)}

Pengujian organoleptik pada jelly drink berbahan dasar buah aren dilakukan oleh 20 orang panelis. Parameter yang dinilai dalam uji organoleptik pada produk pangan jelly drink berbahan dasar buah aren yaitu: warna, tekstur, rasa, dan kekenyalan. Hasil uji organoleptik panelis pada jelly drink berbahan dasar buah aren dapat dilihat pada Tabel 6 dan nilai rata-rata pada Tabel 7 sebagai berikut:

Tabel 6. Nilai panelis uji Organoleptik Jelly drink.

\begin{tabular}{|c|c|c|c|}
\hline No & Parameter & Spesifikasi & Panelis \\
\hline \multirow{4}{*}{1} & \multirow{4}{*}{ Warna } & 5 & 3 \\
\hline & & 4 & 4 \\
\hline & & 3 & 4 \\
\hline & & 2 & 9 \\
\hline \multirow{4}{*}{2} & \multirow{4}{*}{ Rasa } & 6 & 5 \\
\hline & & 5 & 8 \\
\hline & & 4 & 6 \\
\hline & & 2 & 1 \\
\hline
\end{tabular}

\begin{tabular}{cccc}
\hline & & 6 & 5 \\
\cline { 3 - 3 } 3 & Tekstur & 5 & 10 \\
\cline { 3 - 3 } & & 4 & 3 \\
\cline { 3 - 3 } & & 3 & 2 \\
\hline \multirow{3}{*}{4} & \multirow{2}{*}{ Kekenyalan } & 6 & 2 \\
\cline { 3 - 3 } & & 3 & 6 \\
\cline { 3 - 3 } & & 3 & 12 \\
\hline
\end{tabular}

Tabel 7. Nilai Rata-rata Uji Organoleptik

\begin{tabular}{ccc}
\hline Parameter & Total & Rata-rata \\
\hline Warna & 61 & 3,05 \\
\hline Rasa & 96 & 4,8 \\
\hline Tekstur & 98 & 4,9 \\
\hline Kekenyalan & 90 & 4,5 \\
\hline
\end{tabular}

Berdasarkan Tabel 6 dan 7 Nilai panelis dan nilai rata-rata terhadap uji organoleptik penilaian dari 20 panelis dengan menggunakan metode hedonik melalui pengujian organoleptik, panelis memberikan skor terhadap warna jelly drink buah aren yaitu pada rentang 5-2 dengan spesifikasi (bening-keruh). Berdasarkan Tabel di atas terlihat bahwa penilaian uji organoleptik pada parameter warna tertinggi yaitu pada warna keruh dengan jumlah panelis 9 orang sedangkan yang terendah dengan jumlah 3 orang yang memilih warna bening. dimana nilai ratarata presentasi jumlah panelisnya 3,05.

Hasil nilai rata-rata penilaian dari 20 panelis dengan menggunakan metode 
hedonik melalui pengujian organoleptik, panelis memberikan skor terhadap rasa jelly drink buah aren dengan spesifikasi 6-2 (sangat manis-agak tawar). Berdasarkan Tabel di atas terlihat bahwa nilai uji organoleptik pada rasa tertinggi yaitu pada rasa sangat manis dengan jumlah panelis 5 orang sedangkan yang terendah dengan jumlah 1 orang yang memilih rasa agak tawar. Dimana nilai rata-rata presentasi jumlah panelisnya 4,8.

Hasil nilai rata-rata penilaian dari 20 panelis dengan menggunakan metode hedonik melalui pengujian organoleptik, panelis memberikan skor terhadap tekstur jelly drink buah aren dengan spesifikasi 6-3 (sangat-halus - agak-kasar). Berdasarkan Tabel di atas terlihat bahwa nilai uji organoleptik pada tekstur tertinggi yaitu pada tekstur sangat-halus dengan jumlah panelis 5 orang sedangkan yang terendah dengan jumlah 2 orang yang memilih tekstur agak-kasar. Dimana nilai rata-rata presentasi jumlah panelisnya 4,9.

Hasil nilai rata-rata penilaian dari 20 panelis dengan menggunakan metode hedonik melalui pengujian organoleptik, panelis memberikan skor terhadap kekenyalan jelly drink buah aren dengan spesifikasi 6-4 (Sangat- kenyal -Agak kenyal). Berdasarkan Tabel di atas terlihat bahwa nilai uji organoleptik pada kekenyalan tertinggi yaitu pada kekenyalan agak- kekenyalan dengan jumlah panelis 12 orang sedangkan yang terendah dengan jumlah 2 orang yang memilih kekenyalan sangat- kenyal. Dimana nilai rata-rata presentasi jumlah panelisnya 4,5. rangkuman rerata nilai organoleptik warna, rasa, tekstur, dan kekenyalan produk pangan jelly drink berbahan dasar buah aren dapat dilihat pada grafik 1 berikut:

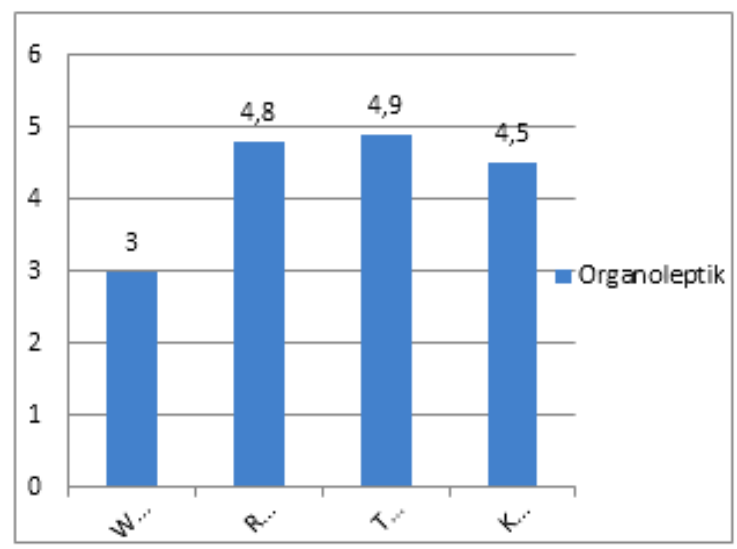

Gambar 1. Rerata nilai organoleptic (warna, rasa, tekstur, dan kekenyalan) produk pangan jelly drink berbahan dasar buah aren (Arenga pinnata MERR)

\section{Uji Kadar Serat Pada Produk Pangan Jelly Drink Berbahan Dasar Buah Aren (Arenga pinnata merr).}

Berdasarkan data hasil analisis kadar serat jelly drink berbahan dasar buah aren tercantum dalam Tabel 5 maka dapat dikatakan bahwa kadar serat jelly drink berbahan dasar buah aren pada dua kali pengulangan tidak jauh berbeda. Kadar serat yang tinggi terdapat pada pengulangan pertama sebesar 0,3446\% dan yang rendah terdapat pada pengulangan kedua sebesar $0,3127 \%$. Dalam penelitian ini hanya dilakukan dua kali pengulangan dalam satu kali pengujian kadar serat.

Pada penelitian tentang kadar serat jelly drink buah aren jika dibandingkan dengan kadar serat yang terdapat pada kolang-kaling yang telah diolah menjadi jelly drink yaitu memiliki rata-rata kadar serat sebesar $0,32865 \%$. Keberadaan serat pada jelly drink berbahan dasar buah aren (Arenga pinnata MERR) dipengaruhi oleh penambahan karagenan pada proses pengolahan jellly drink. Menurut penelitian Yohana (2014) penambahan karagenan berpengaruh pada $\mathrm{pH}$, warna dan tekstur pada jelly drink.

Uji organoleptik Jelly Drink Berbahan Dasar Buah Aren (Arenga pinnata merr) Warna. 
Penentuan mutu bahan makanan pada umumnya sangat bergantung pada beberapa faktor diantaranya cita rasa, warna, tekstur, dan tingkat kesukaan tetapi sebelum faktor-faktor lain dipertimbangkan, secara visual faktor warna tampil lebih dahulu dan kadang-kadang sangat menentukan. Peranan warna suatu makanan adalah sangat penting, karena umumnya kosumen sebelum mempertimbangkan parameter lain, lebih dahulu tertarik oleh keadaan warna makanan tersebut.

Berdasarkan hasil pengamatan pada Gambar 1 yang dilakukan pada jelly drink berbahan dasar buah aren diketahui bahwa warna jelly drink yang dihasilkan adalah jelly drink dengan warna agak keruh dengan skor 3. Hasil uji organoleptik pada warna menunjukan bahwa penambahan air mempengaruhi warna jelly drink ditambah juga dengan warna alami dari buah aren yang berwarna putih agak keruh ketika diolah menjadi jelly drink. Hal ini sejalan dengan penelitian Selviana, (2016) bahwa perlakuan penambahan sedikit air maka semakin banyak sari buah black mulberry yang larut dalam air, sebaliknya dengan penambahan air yang banyak maka sari sari buah black mulberry yang larut dalam air semakin sedikit sehingga mempengaruhi warna dari jelly drink black mulberry. Hasil uji organoleptik yang menyukai warna bening sebanyak 3 orang sedagkan 17 yang tidak memilih warna bening.

\section{Rasa}

Rasa merupakan parameter yang paling berperan dalam penerimaan konsumen terhadap suatu produk. Rasa lebih banyak melibatkan panca indera pengecap yaitu lidah, dengan lidah senyawa dapat dikenali rasanya. Rasa dipengaruhi oleh beberapa factor, yaitu penggunaan bahan dasar, senyawa kimia, suhu konsentrasi, dan interaksi dengan komponen rasa yang lain (Winarno, 2004).

Berdasarkan hasil pengamatan pada Gambar 1 yang dilakukan pada jelly drink berbahan dasar buah aren diketahui bahwa rasa jelly drink yang dihasilkan adalah jelly drink dengan rasa agak manis dengan skor 4,8. Hasil uji organoleptik pada rasa menunjukan bahwa penambahan gula mempengaruhi rasa jelly drink ditambah juga dengan kandungan alami karbohidrat atau gula yang cukup besar dari buah aren.

\section{Tekstur}

Berdasarkan hasil pengamatan pada gambar 1 diketahui bahwa tekstur jelly drink yang dihasilkan adalah jelly drink dengan tekstur agak halus dengan skor 4,9. Pemberian air dan karagenan pada jelly drink berbahan dasar buah aren mempengaruhi nilai organoleptik tekstur jelly drink. Semakin banyak variasi konsentrasi air dan karagenan yang diberikan maka semakin tinggi nilai organoleptik yang diberikan oleh panelis. Hal ini disebabkan karena sifat karagenan yang merupakan hidrokoloid yang dapat membentuk gel, semakin rendah konsentrasi karagenan maka gel yang dihasilkan tidak terlalu disukai dan kadar airnya terlalu tinggi (Selviana, 2016). Hasil uji organoleptik yang menyukai tekstur sangat halus sebanyak 5 orang.

Tekstur suatu bahan akan mempengaruhi bentuk atau wujud yang ditimbulkan oleh bahan tersebut. Air dan karagenan dapat mempengaruhi tekstur jelly drink berbahan dasar buah aren. Air merupakan komponen penting yang mempengaruhi penampakan tekstur dan menentukan daya terima, kesegaran dan daya tahan bahan makanan. Sebagian besar dari perubahan-perubahan bahan makanan terjadi dalam media air yang ditambahkan atau dari bahan tersebut.

\section{Kekenyalan}

Kekenyalan adalah salah satu parameter yang digunakan untuk menguji tingkat kesukaan panelis akan mutu jelly drink berbahan dasar buah aren. Berdasarkan hasil pengamatan pada gambar 1. yang dilakukan pada jelly drink berbahan dasar buah aren diketahui bahwa kekenyalan jelly drink yang dihasilkan adalah jelly drink dengan tekstur agak kenyal skor yang didapat yaitu 4,5. Hasil uji organoleptik pada kekenyalan menunjukan bahwa penambahan karagenan mempengaruhi kekenyalan dari jelly drink (Widawati dan Hardiyanto, 2016). Hasil uji organoleptik yang menyukai kekenyalan sebanyak 2 orang yang memilih kekenyalan sangat kenyal. 
Karagenan merupakan senyawa hidrokoloid yang mampu mengikat air dalam jumlah besar, semakin banyak air yang terikat dan terperangkap menjadikan ruang antar partikel menjadi lebih sempit sehingga larutan bersifat lebih kental atau kenyal. Semakin tinggi konsentrasi karagenan yang ditambahkan maka kekenyalan semakin tinggi, hal ini dapat disebabkan oleh air bebas yang terdapat pada sari buah aren bahkan dari poses penambahan aquades diikat oleh molekulmolekul dari gugus hidrofilik karagenan sehingga berbentuk gel. Semakin tinggi karagenan maka banyak jumlah air bebas yang diserap dan diikat sehingga menyebabkan keadaan jeli lebih kuat dan Semakin rendahnya kadar air maka akan menyebabkan meningkatnya kekenyalan dari jelly drink berbahan dasar buah aren (Sugiarso, 2015).

\section{Implikasi Hasil Penelitian Kepada Masyarakat Taniwel}

Dari hasil analisis produk jelly drink telah diketahui bahwa pada jelly drink yang dibuat ternyata produk pangan nabati jelly drink Buah aren memiliki kandungan serat yang tidak kalah tinggi bila dibandingkan dengan kadar serat produk jelly drink lainnya. Hasil penelitian ini dapat dijadikan sebagai sumber belajar dalam bentuk leaflet yang merupakan salah satu bentuk penyampaian informasi bagi masyarakat pesisir. Leaflet adalah lembaran kertas berukuran kecil mengandung pesan tercetak untuk disebarkan kepada umum sebagai informasi mengenai suatu hal atau peristiwa. Leaflet dimaksud berisi informasi mengenai potensi buah aren sebagai bahan dasar pembuatan jelly drink dan kandungan gizinya. Ratumanan (2004) menjelaskan bahwa fungsi dari pembelajaran adalah membangun pemahaman terhadap pengetahuan.

\section{KESIMPULAN}

kadar serat jelly drink berbahan dasar buah aren berbeda-beda. Pada kode sampel U-I kadar serat sebesar 0,3446 sedangkan pada kode sampel U-II sebesar 0,3127 . Pengujian organoleptik pada jelly drink berbahan dasar buah aren dilakukan oleh 20 orang panelis dengan rerata parameter warna sebesar 3 , rasa sebesar 4,8 , tekstur sebesar 4,9 , dan kekenyalan sebesar 4,5 .

\section{DAFTAR PUSTAKA}

Effendi, D.S. 2009. Aren: Sumber Energi Alternatif. Warta Penelitian dan Pengembangan Pertanian. Tahun 2009; 31(2):1-3.

Lutony TL. 1993. Tumbuhan Sumber Pemanis. Jakarta (ID): PT Penebar Swadaya.

Muchtadi, T. R. 2000. Fisiologi Pasca Panen. Pelatihan Pasca Panen dan Prosesing Hortikultura, 22 Februari 2000, BPLLP Ciawi. Bogor.

Ratumanan, T. G, 2004. Belajar dan Pembelajaran. Semarang. Universitas Negeri Semarang, University Press.

Selviana, S. 2016. Pengaruh Konsentrasi Karagenan dan Gula Pasir Terhadap Karakteristik Minuman Jelly Black Mulberry (Morus nigra L). Universitas Pasundan. Bandung.

Sugiarso, A \& Nisa, F. C. 2015. Pembuatan Minuman Jelly Murbei (Morus alba L.) Dengan Pemanfaatan Tepung Porang (A. Muelleri Blume) Sebagai Pensubtitusi Karagenan. Jurnal Pangan dan Agroindustri. Vol. 3 No 2p. 443452.

Sunanto, Hata. 1993. Aren Budi Daya Dan Multigunanya.Yogyakarta: Kanisius.

Widawati, L \& Hardiyanto,L. 2016. Pengaruh Konsentrasi Karagenan Terhadap Sifat Fisik, Kimia dan Organoleptik Minuman Jeli Nenas (Ananas comosus L. Merr). Universitas Dehasen Bengkulu. Bengkulu.

Winarno, F.G., (2004) Kimia Pangan Dan Gizi, Cetakan Ke-4, PT. Gramedia Pustaka Utama, Jakarta.

Yohana, R. 2016. Karakteristik Fisiko Kimia dan Organoleptik Minuman Serbuk Instan Dari Campuran Sari Buah Pepino (Solanum muricatum, Aiton) dan Sari Buah Terung Pirus (Cyphomandra betacea, Sent). Skripsi. Fakultas Teknologi Pertanian Universitas Andalas. Padang. 